\title{
Micro-lecture Teaching for Improving the Learning Effect of Non-English Majors at North China Electric Power University
}

\author{
Jia-ling HAN $^{1}$ \\ ${ }^{1}$ English Department, North China Electric Power University, Baoding, Hebei, China \\ Correspondence: Jia-ling HAN, English Department, North China Electric Power University, Baoding, Hebei, \\ China.
}

Received: April 23, 2019 Accepted: May 21, 2019 Online Published: May 23, 2019

doi: 10.5539/elt.v12n6p209 URL: https://doi.org/10.5539/elt.v12n6p209

\begin{abstract}
The present study aimed to investigate the effect of micro-lecture teaching on non-English majors' academic achievements and learning motivation. One hundred and twenty-two non-English majors studying the college English course in North China Electric Power University participated in the study. The micro-lecture teaching and traditional PPT teaching were implemented in the two classes respectively. Statistical analysis showed a significant improvement in the academic achievements of the participants $(t=3.128, p<0.05)$ between the pre and post measurements in favor of the post measurement. The results of the questionnaire survey undertaken in the experimental class showed that participants' learning motivations were improved. Accordingly, the researcher concluded that micro-lecture teaching was significantly effective in improving non-English majors' academic achievements and enhancing their learning motivation.
\end{abstract}

Keywords: micro-lecture, college English, academic achievement, learning motivation, ketangpai

\section{Introduction}

\subsection{Research Problem}

College English is a public compulsory course in North China Electric Power University (Bao Ding), but it does not attach much importance to most non-English majors. The tedium of PPT presentation cannot arouse students' interest limiting their enthusiasm and active participation to a certain extent. Many students attend classes under the pressure of attendance, but in fact they do not actively participate in class activities. What's more, North China Electric Power University has significantly reduced the credits of college English, following the current trend of college English teaching reform among Chinese universities. How to improve students' academic achievements and enhance their learning motivation in one-year English study?

With the support of information technology and network development, knowledge transmission can be completed by students themselves before class, and knowledge internalization can be realized in class under the guidance of teachers and peer assistance. Because of the reversed teaching arrangement, the classroom learning process of flipped classroom changes the original teaching mode. The micro-lecture, an essential part of flipped class, combines the multiple advantages of multimodal symbol system and provides a new breakthrough for college English teaching reform and injects new vitality. Therefore, the researcher decided to investigate the use of micro-lecture teaching as a means to improve non-English majors' learning efficiency and learning motivation.

\subsection{Review of Related Literature}

Micro lecture, also called micro course, is the abbreviation of micro audio or video network course. It takes micro-teaching video or audio as the main carrier, and it is a situational online video course resource designed and developed strictly for a certain subject knowledge point (such as key points, difficult points, doubtful points, examination points, etc.) or a certain teaching link (such as teaching activities, subjects, experiments, tasks, etc.) to support a variety of learning methods. As a component of online resources, micro-lecture can adopt online or face-to-face mixed teaching method, and intersperse various learning activities with 3-5 minutes short speech, so as to strengthen the memory of the subject of the course, change students' learning experience, and break through the mindset of course concept.

The prototype of the micro-lecture originated from "the 60-second course" put forward by Professor Mc Grew at 
the University of Northern (1993) and "the one-minute speech" proposed by Kee at the University of Napil (1995). The concept of micro-lecture was first proposed by David Penrose (dubbed as the One Minute Professor) in 2008. He believed that micro-lecture could combine teaching resources with teaching contents and objectives, which could reflect and summarize the core of a course. Its purpose was to guide students to read or explore the course knowledge, provided students with independent learning tasks after class, and let them consolidate the learned knowledge anytime and anywhere.

In China, Hu (2011) first put forward the concept of micro-lecture in view of the low utilization rate of existing educational information resources. According to the new curriculum standards and classroom teaching practice, micro-class takes teaching video as the main carrier to record the organic combination of teaching resources needed in the wonderful teaching and learning activities developed by teachers for a certain knowledge point or teaching link in classroom teaching. Jiao (2013) proposed that micro-lecture was a concise online video which combined learning and teaching applications into a whole, aiming to explain a specific knowledge point.

With the continuous enrichment of practical experience and the deepening of relevant research, micro-lecture was recognized and accepted by more and more people, and its connotation has been constantly developed and enriched. Since 2013, the concept of micro-lecture and related practical activities have been heating up. Many scholars have begun to explore effective micro-course models to promote learning from different perspectives.

Liang et al. (2013) adopted content analysis method, integrated the evaluation standard of online courses and the concept of micro-course as a new analysis framework, and compared the design of representative online learning resources of micro-course (Khan academy, TEDEd and Foshan micro-course) at home and abroad to seek the commonness and characteristics of the concept of micro-course in the construction of micro-course teaching mode. This research broke through the previous research framework. Instead of focusing on the concept and application prospect of micro-course, it made an in-depth review and summary of the micro-course mode in practice, and explored how to effectively improve English learning.

Zhu and Su (2015) constructed a micro-course teaching mode of college English from the perspective of cognitive linguistics, and took college English visual-aural-oral course as an example to discuss how to conduct teaching application. This teaching mode took micro-lecture as the carrier and constructional acquisition as the teaching objective, guiding students to carry out independent learning and personalized learning in the three teaching links of pre-class preview, in-class practice and after-class consolidation.

The rise of Multimodal Discourse Analysis also points out a new direction for micro-course teaching research. Some scholars took college English class as the research object to explore how to use the theory of MDA to guide the production and teaching of micro-course. Compare with traditional English teaching classes, micro-lectures make use of the theory of multimodal discourse analysis to realize the classroom teaching reform, trying to convert the original form of audio-symbol transmission in college English teaching into the integrated use of symbol resource system (Ren, 2016). By making use of mobile learning terminals, the micro-lecture applies fragmented learning concepts to language teaching practice, which can break through the limitations of traditional teaching (Ma, 2015). Through the teaching objectives and tasks, the micro-lectures guide the students through the use of short micro-video as a teaching carrier and the integration of teaching machines, computers and other equipment to carry out teaching activities. Supplemented with reasonable theoretical and practical exercises, micro-lecture can not only achieve the same teaching effect as the traditional teaching mode within one minute, but also can achieve more concentrated and targeted learning experience. It can provide learners with a fresh new learning experience and greatly enhance their autonomous learning awareness (Guan, 2016). Though the micro-lecture is still under construction, it presents a big challenge to traditional English teaching.

In China, the researches on micro-lectures have made some achievements and the design and development of micro-course are becoming more professional. However, the current researches on college English micro-course teaching focus on the teaching applications and application strategies, lacking in-depth empirical research and teaching practice. The use of experimental, investigative or case-study methods is very low. Due to the lack of research tools, the reliability and validity of research results need to be further improved. The relative lack of research methods is bound to limit the research depth of English micro-lesson teaching. The researcher decided to further explore how to design and implement college English micro-courses to enhance EFL learners' learning motivations and improve the effect of EFL at North China Electric Power University. It was hypothesized that there would be a statistically significant difference in the academic achievements of non-English majors between the pre and the post measurements in favor of the post measurement. 


\section{Method}

\subsection{Research Design}

The study was undertaken to explore whether the micro-lecture teaching in college English was more effective than traditional teacher-centered way of teaching in improving students' academic achievements and enhancing their learning motivation.

The research tools used in present study included an experiment and a set of questionnaire. The present study adopted a one-group pre-posttest quasi-experimental design. The scores of English final examinations were used as pretest and posttest to check if there is a difference in students' academic achievements after the experiment.

\subsection{Research Participates}

The subjects of this study were selected from class of 2018 non-English majors in North China Electric Power University. They were from two parallel classes, the experimental class with 60 students and the control class with 62 students. The majority of students were males.

According to the College English Curriculum of North China Electric Power University, a combined teaching mode, i.e. computer-aided self-learning of listening course with classroom teaching has been implemented from the first semester. The subjects from experimental class had a centralized self-learning curriculum arrangement once a week during which they were required to watch the micro-lectures on the library computers.

\subsection{Measure}

In order to evaluate the difference between participants' means of scores on the pre and the post measurements of academic performance, an independent samples t-test was employed for the sake of data analysis of the study. The scores were calculated and measured by the means of SPSS 20.0 (the Statistical Package of Social Science 20.0).

The researcher designed a 15 -item questionnaire which consisted of three components: students' learning efficiency (5 items), learning attitude ( 7 items) and views on micro-lecture teaching ( 3 items), and their views and recognition of the micro-course teaching of college English. A five-point Likert scale was used in order to weigh each item in the questionnaire $(1=$ never; $2=$ rarely; $3=$ sometimes; $4=$ most of the time; $5=$ all the time). Validity of the questionnaire was confirmed when it was reviewed by three TEFL experts who made some changes in the wording of four items. Inter-rater reliability of the observation sheet was calculated using Pearson correlation coefficient and it was $(0.92)$.

\subsection{Procedures}

The experiment was executed in North China Electric Power University, during the 2017-2018 the second semester. The experimental class adopted the micro-lecture teaching method, while the control class employed the traditional PPT teaching method. Both classes used the same teaching content and were taught by the same teacher.

Before the implementation of micro-lecture teaching, the researcher created a number of short videos that covered the key knowledge and skills in each lecture, based on the teaching objectives and content of the college English course. Participants were oriented to micro-lecture teaching during a 16-week class session, where they learnt corresponding knowledge and language skills in the textbooks. After the experiment, a questionnaire was distributed in the experimental class, which included the survey on students' learning attitude and learning efficiency, and their views and recognition of the micro-lecture teaching of college English. All subjects participated in the final examination. Scores of participants in the two classes were statistically compared.

The implementation of micro-lecture teaching went through several steps. Every week, a learning task list and learning resources were distributed to participants for the pre-class autonomous learning via Ketangpai (an online-class management platform). They were required to watch the micro-lecture and complete related exercises and submit their assignments to the researcher before class via Ketangpai. The researcher began each class by asking questions about the content presented in the micro-lectures and also answered questions posed by participants and explained the problems in their homework. And then, the researcher assigned more challenging tasks to participants and guided them to share and comment on the learning achievements. Participants carried on discussions within groups and completed the tasks through peer assistance and collaboration. After class, they were organized to reflect on the experience in the discussion forum of Ketangpai. 


\section{Result}

\subsection{Pre and Post Measurements of Academic Performance}

To evaluate the difference between participants' means of scores on the pre and the post measurements of academic performance, an independent samples t-test was employed for the sake of data analysis. The results of independent samples t-test on pretest revealed the mean, standard deviations, t-values of the scores of English final exams by the two classes which were shown in the Table 1. For convenience, letters were used to represent the two classes, in which Group A was the experimental class and Group B was the control class.

Table 1. Differences in scores on control and experimental classes' pre and post tests

\begin{tabular}{llllll}
\hline & Group & Mean & Std. Error Mean & $\mathrm{t}$ & $\mathrm{p}$ \\
\hline Pretest & A & 71.57 & 7.118 & 0.642 & 0.523 \\
& B & 70.62 & 5.897 & & \\
Posttest & A & 82.69 & 7.319 & 3.128 & 0.003 \\
& B & 76.67 & 9.550 & & \\
\hline
\end{tabular}

As is shown in Table 1, the mean of Group A on pretest was higher than that of Group B $(\mathrm{A}=71.57 ; \mathrm{B}=70.62)$, however, the $\mathrm{p}=0.523>0.05$, which meant that there was no significant difference on pretest performance between the two groups, i.e., the English achievements of the two groups were the same before the experiment. The mean of Group A on posttest was higher than that of Group B $(\mathrm{A}=82.69 ; \mathrm{B}=76.67)$ and the t-test revealed that the difference was statistically significant as t-value was 3.128 at the 0.05 level of significance. It suggested that the two groups had remarkable difference in the overall level of English, after a semester of teaching experiment, the experimental group and control group were improved, but the improvement of experimental group was significantly higher than the control group.

\subsection{Questionnaire Survey Results}

At the end of the semester, the author conducted a questionnaire among the students of experimental class, including learning attitude, learning efficiency and evaluation of college English micro-lectures. See the Table 2 below.

Table 2. Students' feedback table of college English micro-lecture teaching

\begin{tabular}{|c|c|c|c|c|c|}
\hline Items & $\begin{array}{l}\text { Strongly } \\
\text { disagree }\end{array}$ & disagree & neutral & agree & $\begin{array}{l}\text { Strongly } \\
\text { agree }\end{array}$ \\
\hline I'm satisfied with the college English micro-lectures. & $6.23 \%$ & $12.16 \%$ & $11.78 \%$ & $31.51 \%$ & $38.32 \%$ \\
\hline $\begin{array}{l}\text { I think the micro-lecture teaching is less interesting } \\
\text { than traditional PPT class. }\end{array}$ & $43.03 \%$ & $37 \%$ & $14.7 \%$ & $5.27 \%$ & $0 \%$ \\
\hline $\begin{array}{l}\text { The micro-lecture teaching cannot improve the } \\
\text { efficiency of my English learning. }\end{array}$ & $48.11 \%$ & $27.23 \%$ & $13.41 \%$ & $8.11 \%$ & $3.14 \%$ \\
\hline I have no interactions with my English teacher. & $33.82 \%$ & $28.91 \%$ & 13.59 & $21.53 \%$ & $2.15 \%$ \\
\hline $\begin{array}{l}\text { I make best use of every chance to speak English in } \\
\text { class. }\end{array}$ & $4.21 \%$ & $23.69 \%$ & $10.87 \%$ & $22.09 \%$ & $39.14 \%$ \\
\hline $\begin{array}{l}\text { I will not attend the English class if I have the } \\
\text { chance. }\end{array}$ & $34.64 \%$ & $27.1 \%$ & $22.73 \%$ & $8.61 \%$ & $6.92 \%$ \\
\hline I can participate in class discussions actively. & $5.17 \%$ & $11.13 \%$ & $18.31 \%$ & $34.36 \%$ & $31.03 \%$ \\
\hline $\begin{array}{l}\text { I accumulate vocabularies consciously in and after } \\
\text { class. }\end{array}$ & $3.04 \%$ & $10.33 \%$ & $18.09 \%$ & $30.57 \%$ & $37.97 \%$ \\
\hline $\begin{array}{l}\text { I will download the college English micro-lectures to } \\
\text { study anytime and anywhere on my computer or } \\
\text { mobile phone. }\end{array}$ & $3.71 \%$ & $10.85 \%$ & $12.73 \%$ & $30.06 \%$ & $42.65 \%$ \\
\hline
\end{tabular}




\begin{tabular}{|c|c|c|c|c|c|}
\hline $\begin{array}{l}\text { I will spend great effort on English learning after } \\
\text { class. }\end{array}$ & $3.69 \%$ & $9.2 \%$ & $20.95 \%$ & $28.05 \%$ & $38.11 \%$ \\
\hline $\begin{array}{l}\text { The micro-lectures enhanced my ability to plan for } \\
\text { learning. }\end{array}$ & $4.72 \%$ & $8.41 \%$ & $18.23 \%$ & $26.88 \%$ & $41.76 \%$ \\
\hline I won't keep learning after achieving English credit. & $23.07 \%$ & $25.43 \%$ & $31.07 \%$ & $13.61 \%$ & $6.82 \%$ \\
\hline $\begin{array}{l}\text { I didn't seriously } \text { accomplish } \\
\text { assignments. }\end{array}$ & $35.01 \%$ & $29.41 \%$ & $19.09 \%$ & $12.84 \%$ & $3.65 \%$ \\
\hline $\begin{array}{l}\text { The micro-lectures enhanced my ability of } \\
\text { independent learning. }\end{array}$ & $4.06 \%$ & $10.78 \%$ & $18.49 \%$ & $25.73 \%$ & $40.94 \%$ \\
\hline $\begin{array}{l}\text { The micro-lectures developed my ability of } \\
\text { teamwork skills. }\end{array}$ & $2.74 \%$ & $10.13 \%$ & $23.58 \%$ & $27.66 \%$ & $35.89 \%$ \\
\hline
\end{tabular}

A total of 122 questionnaires were issued and 122 valid ones were received. The efficiency of the questionnaire was $100 \%$. According to the questionnaire survey, nearly seventy percent of the students $(69.83 \%)$ were satisfied with the micro-lecture teaching of college English; more than eighty percent of the students $(80.03 \%)$ thought the micro-lecture teaching was more interesting than traditional PPT class; about seventy-five percent of the students (75.34\%) improved their English learning efficiency in the micro-lecture teaching; $62.73 \%$ of the students had more interactions with the English teacher; 61.23 percent of the students made best use of every chance to speak English in class; $61.74 \%$ of the students would attend English class; $65.39 \%$ of the students actively participated in class discussions; $68.54 \%$ of the students accumulated vocabularies consciously in and after class; $72.71 \%$ of the students would download micro-lectures to study anytime and anywhere on computers or mobile phones; $66.16 \%$ of the students spent great effort on English learning after class; $68.64 \%$ of the students enhanced their abilities to plan for learning in micro-lectures; only $20.43 \%$ of the students would not keep learning after achieving English credit; $64.42 \%$ of the students seriously accomplished after-class assignments; $66.67 \%$ of the students enhanced their abilities of autonomous learning in micro-lectures; $63.55 \%$ of the students developed their abilities of teamwork skills in micro-lectures.

According to the results of the questionnaire survey, the majority of students believed that the course gave them a sense of satisfaction and improved their comprehensive abilities in teamwork, learning planning, independent learning. Students were willing to invest time and energy in English study and learn relevant knowledge outside the classroom. Compared with the traditional PPT teaching, the micro-lecture teaching has played a positive role in college English learning.

\section{Discussion}

The purpose of the present study was to investigate the effect of micro-lecture teaching on non-English majors' academic achievements and learning motivation. Statistical analysis of the pre-post tests showed a significant difference in favor of the post measurement $(\mathrm{t}=3.128, \mathrm{p}<0.05)$. Therefore, it can be said that the micro-lecture teaching improved non-English majors' academic achievements. The results of the questionnaire survey indicated that the micro-lecture teaching was more effective in enhancing participants' learning motivations.

A possible justification for the result of the present study may be that compared with PPT or other learning resources, micro-lectures are short and concise. The knowledge points are concentrated in 5-10 minutes which is in line with the 10-minute principle of attention. This learning style conforms to the characteristics of modern students' fragmented learning. Students, especially for those with poor English proficiency, can download micro-lectures to their mobile phones and computers and review the key knowledge explained by the teacher in micro-lectures anytime and anywhere. Moreover, they could control the pace as well as the number of views of the micro-lectures through replaying and pause, so that students have more time to think and can highly focus on learning.

Another possible reason for this result is the effect of active learning activities. The micro-lecture teaching replaces in-class lectures with active student engagement in class activities, with the main content provided before class. Through peer-assisted learning, students may deepen the internalization of knowledge, truly cultivate their ability to use English flexibly, and reduce the phenomenon of learning without using before. Meanwhile, students can interact with teachers and get timely feedback, which improves the learning efficiency.

What's more, through the micro-lecture platform of college English, teachers and students can share excellent 
English video and movie clips, expand the scope of students' English learning, and cultivate and improve students' intercultural communication ability and comprehensive English application ability.

\section{Conclusion}

The result reached in the present study led the researcher to conclude that the micro-lecture teaching could significantly improve non-English majors' academic achievements and enhance their learning motivation. This teaching mode can be adopted in other courses or used by other teachers in North China Electric Power University.

In light of the result of the present study, the following points are recommended:

First, it is necessary to establish a diversified autonomous learning monitoring system with full participation in college English autonomous learning under the big data environment with high efficiency and self-supervision under the active intervention of teachers and other external factors. The construction of the system is mainly composed of self-monitoring, teacher monitoring, supervision monitoring, educational monitoring, technical monitoring and other modules. Through the multi-monitor system, teachers can timely guide students to correct learning attitude, adjust learning strategies, and effectively use learning resources and modern information technology for independent learning, so as to achieve the predetermined learning purpose.

What's more, the evaluation mechanism combining formative evaluation and summative evaluation should be adopted. Teachers should make effective records of students' online learning and participation in daily activities, so that students' learning can be brought under effective management and supervision. At the same time, self-evaluation, student mutual evaluation and other methods will be carried out. By making students internalize classroom knowledge, teaching and learning interaction, querying students' online learning time, visiting site record, learning frequency and other ways, teachers can track students' learning process and evaluate students' learning progress and effect.

\section{Acknowledgement}

This research is supported by the Fundamental Research Funds for the Central Universities under Grant No. 2019MS146.

\section{References}

Arnold, J. (2000). Affect in Language Learning. Foreign Language Teaching and Research Press.

Brown, H. D. (1994). Teaching by Principles: An Interactive Approach to Language Pedagogy. New Jersey: Prentice Hall.

Chen, X. (2017). Survey and Strategy Analysis of Micro-lecture English Teaching under Technology Information Background. Journal of Educational Institute Jilin Province, 33(10), 79-81.

Clément, R., \& Kruidenier. (1985). Aptitudes, attitude and motivation in L2 proficiency: A test of Clément's model. Journal of Language and Social Psychology, 4(1), 21-37. https://doi.org/10.1177/0261927X8 500400102

Crookall \& Oxford, R. (1985). Social psychological and L2 learning: The role of attitudes and motivation by R. C. Gardner. Language Learning, 38(1), 127-139. https://doi.org/10.1111/j.1467-1770.1988.tb00404.x

Cook, G., \& Seidlhofer, B. (1995). Principles \& Practice in Applied Linguistics. Oxford University Press.

Dickinson, L. (1995). Autonomy and motivation: A literature review. System, 23, 165-174. https://doi.org/ $10.1016 / 0346-251 X(95) 00005-5$

Dörnyei, Z. (1990). Conceptualizing motivation in foreign language learning. Language Journal, 40(1), 45-78. https://doi.org/10.1111/j.1467-1770.1990.tb00954.x

Dörnyei, Z. (1994b). Understanding L2 Motivation: On with the Challenge. Modern Language Journal, 78, 515-523. https://doi.org/10.1111/j.1540-4781.1994.tb02071.x

Dörnyei, Z. (2001). Teaching and Researching Motivation. Continuum, Person Education Limited Inc.

Ellis, R. (2014). The Study of Second Language Acquisition (2nd ed.). Shanghai Foreign Language Education Press.

Gardner, R. C., \& Lambert, W. E. (1972). Attitudes and Motivation in Second Language Learning. Rowley: Newbury House.

Gardner, R. C. (1985). Social Psychology and Second Language Learning: The Role of Attitudes and Motivation. 
London: Edward Arnold.

Gregory, S. M., Teodora, R. S., \& Kathleen, E. C. (2013). Comparing the Effectiveness of an Inverted Classroom to a Traditional Classroom in an Upper-Division Engineering Course. IEEE Transactions on Education, 56(4), 430-435. https://doi.org/10.1109/TE.2013.2249066

Guan, Y. (2016). A Study and Practice of College English Micro-lecture Teaching Based on Multimodal Discourse Analysis-with Nanfang College of Sun Yat-sen University as an Example. Journal of Jilin Engineering Normal University, 32(6), 84-87.

Harmer, J. (2000). How to Teach English. Foreign Language Teaching and Research Press.

$\mathrm{Hu}$, T. (2011). "Micro-course": the new trend of regional education information resources development. E-Education Research, 222(10), 61-65.

Jewitt, C. (2002). The Move from Page to Screen: The Multimodal Reshaping of School English: Visual Communication. Journal of Visual Communication, 1(2), 171-195. https://doi.org/10.1177/14703572 0200100203

Jewitt, C., \& Kress, G. (2003). Multimodal Literacy. New York: Peter Lang.

Jeff, B., \& Kress, G. (2008). Writing in multimodal texts-a social semiotic account of designs for learning. Written Communication, 25(2), 171-172. https://doi.org/10.1177/0741088307313177

Jiao, J. L. (2013). Micro lesson and its application and influence. Information technology for primary and secondary schools, 4, 13-14.

Kaltenbacher, M. (2004). Perspectives on multimodality: From the early beginnings to the state of the art. Information Design Journal Document Design, 12(3), 190-207. https://doi.org/10.1075/idjdd.12.3.05kal

Kanfer, R., \& Ackerman, P. L. (1989). Motivation and cognitive abilities: An integrative/aptitude-treatment interaction approach to skill acquisition. Journal of Applied Psychology-Monograph, 74, 657-690. https://doi.org/10.1037/0021-9010.74.4.657

Kelly, B. B. (2014). The Effects of Motivation on Achievement and Satisfaction in a Flipped Classroom Learning Environment. Arizona: Northcentral University.

Kelly, E., \& Snowden, B. A. (2012). Teacher Perceptions of the Flipped Classroom: Using Video Lectures Online to Replace Traditional in-class Lectures. Texas: University of North Texas.

Keller, J. M. (1983). Motivation Design of Instruction. In C. M. Reigeluth (Ed.), Instructional design theories and models (pp. 386-433). Hillsdale, NJ: Erlbaum.

Kevin, R. C. (2013). Examining the Effects of the Flipped Model of Instruction. Capella: Capella University.

Kress, G., \& Van Leeuwen, T. (2001). Multimodal Discourse: The Modes and Media of Contemporary Communication. London: Arnold.

Lawn, M. (1999). Designing teaching: The classroom as a technology. In I. Grosvenor, M. Lawn, \& K. Rousmaniere (Eds.), Science and images: The social history of the classroom (pp. 65-82). New York: Peter Lang.

Liang, L., Cao, Q. \& Zhang, B. (2013). Research on a Micro-lecture Design Model through Comparative Case Study. Open Education Research, 19(1), 65-73.

Ma, A. (2015). Practice and exploration of college English micro-course teaching under multi-modal discourse analysis. Journal of Hunan University of Science and Engineering, 36(12), 188-191.

Mitchell, T. R. (1982). Motivation: New Direction for Theory, Research and Practice. Academy of Management Review. https://doi.org/10.2307/257251

Noels, K. A., Pellier, L. G., \& Clément, R. (2000). Why are you learning a second language? Motivation orientation and self determination theory. Language Learning, 50(1), 57-85. https://doi.org/10.1111/0023-8333.00111

O’ Halloran, K. L. (2004). Multimodal Discourse Analysis: Systemic-Functional Perspectives. Continuum.

Oxford, R., \& Shearin, J. (1994). Language learning motivation: Expanding the theoretical framework. Modern Language Journal, 78(1), 12-28. https://doi.org/10.1111/j.1540-4781.1994.tb02011.x

Ren, L. (2016). Exploration of college English micro-course teaching reform under the guidance of multi-mode theory. Mechanical Vocational Education, 11, 42-44. 
Shah, J. Y., \& Gardner, W. L. (2008). Handbook of Motivation Science. New York: The Guilford Press.

Shieh, D. (2009). These lectures are gone in 60 seconds. Chronicle of Higher Education, 55(26), A1, A13.

Tremblay, P. F., \& Gardner, R. C. (1995). Expanding the motivation construct in language learning. The Modern Language Journal, 79, 505-518. https://doi.org/10.1111/j.1540-4781.1995.tb05451.x

Van Lier, L. (1996). Interaction in the Language Curriculum: Awareness, Autonomy and Authenticity. London $\&$ New York: Eddison Wesley Longman.

William, M., \& Burden, R. (2000). Psychology for Language Teachers. Beijing: Foreign Language Teaching and Research Press.

Zhu, J., Su, X. J. (2015). The Construction and Application of Micro-class Mode of Instruction-With a Focus on College English Visual-aural-oral Course. TEFLE, 165(9), 21-25.

\section{Copyrights}

Copyright for this article is retained by the author(s), with first publication rights granted to the journal.

This is an open-access article distributed under the terms and conditions of the Creative Commons Attribution license (http://creativecommons.org/licenses/by/4.0/). 